\title{
Irish Criticism and the Political
}

\section{Conor McCarthy}

To cite this article: Conor McCarthy (2010) Irish Criticism and the Political, Wasafiri, 25:2, 59-64, DOI: $10.1080 / 02690051003651969$

To link to this article: https://doi.org/10.1080/02690051003651969

$$
\text { Published online: } 11 \text { May } 2010 .
$$

Submit your article to this journal ए]

\section{Џlll Article views: 87}

Q View related articles $\square$ 


\section{Irish Criticism and the Political}

\section{Conor McCarthy}

\section{I}

It is risky, for either author or reader, to hold criticism responsible to the current moment. This is a pitfall largely avoided by both Joe Cleary's recent Outrageous Fortune and by Declan Kiberd's Irish Classics, though for different reasons. As Cleary says, the risk in the contemporary moment is that 'elation at overcoming a difficult history will serve only to reduce the space for debate, and to consolidate new orthodoxies as disabling as any that prevailed in the past' (1-2). The sense that Cleary wrote this at the pinnacle of the recent boom does not prevent us realising that the converse is also true; pessimism in the context of financial crisis, economic recession, a sterile politics and an academic and intellectual sphere largely passive in the face of a hostile state should not lead us to conclude that the present moment is one without opportunities for criticism. The question is, how does criticism respond to such openings?

Here is Cleary's definition of the job of criticism:

The proper business of any critical theory is not to validate a pregiven political position, whether to the left or right. It is, rather, to track the matrix of oppressive and emancipatory forces at work in every period of modernity, and indeed to be attentive to how even the most emancipatory developments can sometimes collude with or be commandeered by the regressive. (7)

Cleary offers a series of interpretative surveys of a variety of Irish critical discourses - aesthetic ideology, the historiography of the novel, naturalism, tragedy - whose great power and usefulness lies precisely in their long-range frameworks. Arguing that Irish literary-intellectual debate has been dominated for the last couple of decades by the three discourses of revisionism, feminism and postcolonialism, Cleary points out that these modes nevertheless share a great deal in common: the class background and professional academic status of most of their adherents; their attitudes to modernisation; their tendency to see themselves as 'dissenting'; and their approach to the 'politics' of the text. Cleary identifies

a widespread tendency to equate political engagement and analysis with thematizing 'the political' in literary or other cultural texts. Conceived thus, political analysis in the cultural sphere essentially amounts to producing new readings of cultural texts or artefacts that foreground political or social themes. The analytical idioms in such cases will undoubtedly be very up-to-the-moment, but the actual practice (whether in revisionist or postcolonialist or feminist or in queer studies, and so on) will still remain broadly consonant with the older modes of 'ethical' criticism characteristic of the discipline of literary criticism at its bourgeois meridian. Whether the object of analysis is a high modernist literary text or popular film, a work of visual art or music, the debate in such instances will predictably be conducted mainly at the level of the semiotic content of the text. (3-4)

Such criticism takes no interest in a sociology of culture or its instrumentalities, no interest in the institutional or commercial apparatuses by which culture is made, authorised, disseminated, commodified; taught, reproduced, displayed as symbolic capital; deployed by the machinery of the state or great corporations. How these apparatuses or processes affect criticism itself is even further off the map. Cleary admits that his own book does not go far in this direction, though the form of his essays marks a refreshing break from the focus on one text or a handful of texts that characterises most Irish critical essays.

Cleary concludes his opening essay by referring to Perry Anderson's reading of Francis Fukuyama. Anderson notes Fukuyama's rightwing triumphalism, yet accepts that the capacity of the global Left to offer a political or economic alternative to capitalism and liberal democracy is almost nil; in Cleary's pithy gloss, 'capitalism's difficulty is not necessarily socialism's opportunity' (9). While the Marxist critique of capitalism only becomes more relevant and useful, the capacity of the Left to elaborate a political project that has not 
always already surrendered to the capture of the logic of neoliberal modernisation becomes only weaker. The point is not that alternatives to the status quo cannot be imagined; it is rather that the alternatives on offer seem to be only slight variations on the present. Cleary's book seems to me to dramatise a very particular moment and impulse. On the one hand, Cleary offers one of the most brilliant and thoroughgoing critiques of contemporary Irish culture we have. On the other, he admits the political powerlessness of such criticism.

A much more optimistic view was offered by Declan Kiberd in 2000 in his magisterial overview of Irish Classics. In the final chapter, Kiberd responds to the Good Friday Agreement, and sees a positive future for Irish criticism. Accepting that Irish Studies has always been 'a crisis-driven discipline' (620), Kiberd nevertheless sees positive, even utopian, possibilities in it and its objects. Yet, he tells us, from the 1920 s to the 1960 , English departments in Ireland worked mostly with exercises in 'ventriloquism' (623). Criticism of Anglo-Irish literature developed mostly outside of Ireland. Work which sought to establish continuities between Gaelic Irish and Anglophone Irish literature, such as Vivien Mercier's The Irish Comic Tradition (1962), were ambivalently received. For Kiberd, the most notable critique of Mercier's book came from Conor Cruise O'Brien, who perceived an essentialism underlying the continuities of Mercier's historical narrative. O'Brien suggested that the Irish 'tradition' was a more fragmentary formation, imposed on the materials of culture for pragmatic reasons. The situation was better described in terms which Kiberd calls 'behaviourist', but which have a materialist ring to them; 'Irish minds', or mentalites, are responses to the 'Irish predicament' (625). From the Mercier-O'Brien debate, Kiberd traces a bifurcated heritage of much contemporary Irish criticism, with Seamus Deane leading the Mercians, and Edna Longley leading the O'Brienites. But in the 1950 s and 1960 s Richard Ellmann, for all his labours and critical sympathy, essentially saw Irish literature as increasingly modern to the extent that it sloughed off its Irishness or transcended its context. Kiberd sees himself, of course, as arguing to the contrary. Modernity, he says, has been the constitutive Irish experience. The modernism of Irish literature has been coded into the Belfast Agreement, he argues, placing it in a lineage dating back to Charlotte Brooke's Reliques of Irish Poetry. In the Agreement, with its assumption of the re-writing of the 1937 Constitution so as to drop the territorial claim, Kiberd discerns the final emergence of a national culture, successfully flensed of political nationalism:

Even as political nationalism disappears, a truly comprehensive national culture may for the first time be born. After all, political nationalism was just another in the long line of attempts to cope with modernity - it was nothing more than a means by which to implement the Celtic values of a people which had never achieved a satisfactory embodiment under the British imperial scheme. By attaching itself to forms of the state inherited from British days and by leaving those forms unmodified, it doomed itself to frustration, to mistaking the means of liberation for the end in itself. The Belfast Agreement at least gives everyone the chance to start again. It may in time produce political and cultural models that could be of use to communities in other war-torn parts of the world, where the problem of 'blood and belonging' cries out for cultural rather than military solutions. Its central intuition - that an unprecedented knowledge is possible in zones where cultures collide - would not have fazed any of the major writers treated in this book. The seeds of the Belfast Agreement were sown in the works of Irish literature [...]. (631)

One notes here Kiberd's culturalist or idealist conviction that the ideas embodied in Irish culture are the driving force of Irish society. If in the middle 1990 s he suggested that Irish writers had invented the nation, now he is suggesting that that grand narrative has dissolved itself at the level of the political, the Belfast Agreement being the last text in that tradition. Irish literature can now be 'unblemished by Irishness, but securely Irish' (Deane 58). Other more glancing points show interesting slippages. The Belfast Agreement now appears a positive form of the Cultural Traditions programme, which asserts 'parity of esteem' for rival 'cultures' in the North. Kiberd's conclusion is the assertion that the telos of the Irish literary tradition is the Belfast Agreement. 'The future is, as Oscar Wilde tells us, what artists already are', Kiberd argues (617), evoking Ernst Bloch's idea of 'anticipatory illumination' (Bloch 141-55 passim). It would be inaccurate to suggest that Kiberd characterises the Agreement as a utopian document, but it is striking to see a critic willing to stake so much on the present moment.

II

Though both Cleary and Kiberd are identified with Irish postcolonial criticism, they are evidently very different in both method and mood, and in their attitudes to political criticism. What is notable is that the critic whose work most overtly displays its theoretico-political resources is also the one who is most pessimistic politically. By this I do not simply mean that Kiberd's optimistic liberal republicanism bases its sense of hope on an international treaty, while Cleary's pessimistic Marxism grounds its disillusion in the inevitability of a crisisracked capitalism. What is interesting also is the sense that each has or embodies for criticism itself.

Cleary's model is based on that of the Frankfurt School thinkers. Its emphasis on 'critical theory', on the contradictions of modernisation and on the potential for domination in the midst of apparent liberalisation, all point towards the disenchanted view of post-Enlightenment culture summed up by Adorno and Horkheimer. This is a critical heritage that ultimately dates back to the young Marx. For the Marx of the 1844 Manuscripts, radical philosophy was grounded in the social world; a philosophy that could not be turned out to the world was not living up to its radical intention. If the root of his philosophy was 'man', man's 
primary characteristic was alienation. In the Eleventh Thesis on Feuerbach, Marx famously suggested that earlier philosophers had tried to understand the world; the real challenge is to change it. This view was developed by mid-twentieth-century Marxists, most notably Lukács, and then Marcuse and Horkheimer. To the Frankfurt thinkers, bourgeois philosophy was contemplative, but Critical Theory was to be active. Bourgeois philosophy stands outside of the world of fixed objects and structures which it gazes at; Critical Theory is active - the contemplative separation of subject and object was to be broken by dialectical interaction which would make change possible in both. In Dick Howard's gloss,

Understanding the world is possible only through the action which changes it; changing the world transforms the subject whose philosophical questioning of its conditions of possibility inaugurated the critical dialectic that opens the path to radical politics. (2)

Yet this activist rhetoric seems to belong more to Kiberd than to Cleary. Kiberd is more evidently confident of the place of criticism in the world. If Irish literature contains within itself the seeds of the future, as Kiberd suggests, then the critic whose task it is to provide the kind of reading which elucidates that anticipatory illumination will never lack for a role. Kiberd practises a Blochian historicism, which reads backwards even as it narrates forwards in cultural history. Such a Whiggish structure of intellectual feeling inevitably justifies the social and political position of the critics who enact it. With Cleary, by contrast, we get a pessimistic narrative predicated fundamentally on the political limitations of post-Revival 'neo-naturalist' aesthetics. Cleary's work sits unhappily at a point where the progressive Hegelianism of Lukács and Jameson, at the level of critical method, runs aground on the entropic Hegelianism of Kojève and Fukuyama, at the level of the political. So resolute is Cleary's focus on neo-naturalism as a cultural dominant, so pessimistic is he about the critical resources of late Irish modernism or postmodernism, that even the last essay on the Bachanalian carnival of the Pogues must conclude with a cleverly Adornian formulation of the 'integrity' of their putative 'failure' (Cleary 226).

Paradoxically, allusions to 'political criticism' derive their force from the fact that criticism takes place on the terrain of civil society. With Jurgen Habermas and Reinhart Koselleck, in fact, we can say that criticism is constitutive of civil society. Civil society is itself a term open to debate and with a varied semantic heritage. It is in the Philosophy of Right (1821), however, that Hegel gives us the modern sense of the term. Civil or bourgeois society, the realm of individuals who have left the unified space of the family to enter into competitive economic relations with each other, is to be contrasted with the State. Hegel sees civil society as configured mostly by private interests and economic activities. Yet he also sees civil society as including various civic and social institutions which organise and govern economic life, leading by a process of education to the rational life of the state. The particularity of civil life blends over into the universality of the state. For Hegel, this is necessary as, unlike earlier thinkers, he sees no inherent rationality in civil society.

With Marx, the meaning of civil society narrows considerably. The term now refers chiefly to economic interests and activities, crass egotism and materialism. Civil society arose on the ruins of mediæval society, where individuals were organised in guilds and estates, each of which possessed a political role. As these organisations or partial societies broke down, civil society arose as the space of atomised individuals, linked only by the law. The broken and conflictual character of civil society requires a politics which is abstracted from it. The modern state is necessitated but also determined by these characteristics of civil society. The political identity of individuals as citizens in modern society is separated from their civil identity, and from their work in the productive sphere of economic relations, whether as bourgeois capitalist or as wage-labourer: 'The political revolution ... abolished the political character of civil society' (Marx 232). Marx contrasts the idealism of universal interests as represented in the state, and the abstracted concept of a citizen who is moral because he goes beyond his narrow interest, with the materialism of the real sensuous in civil society:

But the perfection of the idealism of the state was at the same time the perfection of the materialism of civil society. The shaking-off of the political yoke was at the same time the shaking-off of the bonds which had held in check the egoistic spirit of civil society. Political emancipation was at the same time the emancipation of civil society from politics, from even the appearance of a universal content. (233)

For the struggle of civil society to be ended, and for the full potential of human beings to be realised, a revolution must take place; civil society and the political society it helps to produce must be set aside, and a social as well as political revolution take place.

The major theorist of civil society in Marx's wake was Antonio Gramsci. Gramsci enacts a return to Hegel in his formulations, which are broader and more positive than those of Marx. To Gramsci, civil society is the home not merely of individuals, but of organisations, and it is capable of rational self-regulation and freedom. He picks up on Hegel's sense that the estates and corporations are organising elements which represent corporate interests in a collective way, and equally that the bureaucracy and legal system help to regulate civil society and link it to the state. The separation of state and civil society is analytically useful but not a practical reality. Even a policy of non-interference is still formulated by a state. The reality is the interpenetration of state and civil society; the state is cushioned by hegemony organised and won in civil society; the hegemony of the ruling class is backed by the coercive power of the state. The state has an 'ethical' function, 
in that it tries to educate public opinion and intervene in the economy; while custom and habit can exert a function through civil society related or analogous to law. Though he argues that state and civil society are deeply imbricated with each other, Gramsci equally stresses that they are not identical to each other. Recognising that the state has a role in the development of civil society, Gramsci nevertheless is wary of state-worship. Rather, in fact, he reformulates Marx's idea of the withering away of the state as the realisation of the selfregulating capacity of civil society.

\section{III}

In Ireland, and in Northern Ireland specifically, thought and work on culture and society issued in the 1980s in groups such as those around the avant-garde journal The Crane Bag, and later the Field Day Theatre Company, groups of which Declan Kiberd was a member, and of which Joe Cleary is arguably a legatee. However, neither The Crane Bag nor Field Day could properly be understood as Marxist or Gramscian in their formation. The Crane Bag's main intellectual inspiration was Heideggerian hermeneutics, and its governing metaphor was that of the 'fifth province', an imaginary space where the conflicts and difficulties besetting the four terrestrial and historical provinces of Ireland could be resolved on the level of ideas. Ireland's problems were those of identitarian politics and cultural 'atavism':

There must be a no-man's land, a neutral ground where things can detach themselves from all partisan and prejudiced connection and display themselves as they are in themselves... This province, this place, this centre, is not a political position. In fact, if it is a position at all, it would be marked by the absence of any particular political and geographical delineation, something more like a disposition. (Hederman and Kearney 3-4)

Field Day was more politicised, but with the same idealist emphasis. In 1984, Seamus Deane was arguing that the Northern crisis was essentially 'a crisis of language - the ways in which we write it and the ways in which we read it' (46). In a 1982 interview, Brian Friel had already suggested that the Company aimed at figuring and creating 'a cultural state, not a political one', out of which 'a possibility of a political state follows' (O'Toole 21).

So the primacy of culture and criticism over the state and political society is evident in both The Crane Bag and Field Day. Both projects were confident that the realm of civil society was the space from which the problems of political society could be examined and resolved. Both The Crane Bag and Field Day drew their contributors chiefly from academia, but they operated outside of the academy. They operated, nevertheless, with a sense of the relationship of culture and the state that was more indebted to the Romantic idealism of Friedrich Schiller than to the cultural materialism of Gramsci. It was in his letters On the Aesthetic Education of Man that
Schiller argued that aesthetic pedagogy was an essential prerequisite to the founding of a rational state. Confronting the political turmoil of his own time, Schiller considers 'that most perfect of all the works to be achieved by the art of man: the construction of true political freedom' (7). Schiller's ambition in the letters is to establish the principle

that if man is ever to solve that problem of politics in practice, he will have to approach it through the problem of the aesthetic, because it is only through Beauty that man makes his way to Freedom. (9)

The rational state can only be achieved once the split within man is ... healed, and his nature so restored to wholeness that it can itself become the artificer of the State' (45).

It seems reasonable to suggest that this appears to be the thinking that underlies the Field Day project. Both The Crane Bag and Field Day showed little reflexive consciousness of their own location on the terrain of civil society, while fully confident in their ability to mould or even to reformulate the terrain of the political. These groups had a Gramscian interest in the role of intellectuals, but little of his sense of the materiality or institutional imbrications of culture, or of its relationship to the state, which were conceived more in Romantic terms. One must acknowledge the boldness of both The Crane Bag and the Field Day projects, which sought to create a counter-public sphere by the sheer force of their work, while also identifying their weaknesses. The cultural/civil was deemed essential to the political, but the importance of the political to the cultural/civil was neglected.

And this remains the case with both Kiberd and Cleary, albeit with different inflections. Both writers are deeply concerned with modernity, a crucial category for Irish criticism and intellectual life over the last four decades. Kiberd wishes to stress the modernity of Irish writers: "my contention is that, for writers as disparate as 0 Bruadair and Yeats, to be Irish was to be modern anyway, whether one liked it or not' (628). Modernity, for Kiberd, is firstly an attribute of individual writers; his exemplary figures are 'Tory anarchists', 'aristocratic radicals', 'protesting nostalgists', Janus-faced figures who combine in their work and in their performative selves elements of past and present in the act of making an anticipated future. Yet there is in Kiberd an elision between the modernity of such writers, and modernity as a periodising historiographic concept of the transition between a 'traditional' society and a 'modern' one. Exactly when this 'modernity' emerged or took place is never quite clear, but this movement is held to be basically positive. Cleary is, in the manner of Horkheimer and Adorno, more attuned to the problematics and contradictions of modernity, but it is nevertheless his remit; the task of a properly 'critical theory' is to 'track the matrix of oppressive and emancipatory forces at work in every period of modernity' (Cleary 7 ) — in short, to track the dialectic of enlightenment.

But criticism as we know it is itself a creature of enlightenment and modernity, and its rise has been concurrent 
with that of the modern state. The very relationship of civil and political society we traced through Hegel, Marx and Gramsci is a primary characteristic of modernity. Critics such as Kiberd and Cleary are very interested in modernity as a set of cultural ideas and experiences, but pay less attention to modernity as a set of socio-political institutions and structures, less still to the relationship between modernity and the critical institution itself. Whereas Habermas's 1980 defence of modernity characterises it as 'an incomplete project'; glossing Weber, he suggests that cultural modernity consists in 'the separation of the substantive reason expressed in religion and metaphysics into three autonomous spheres' (9). These spheres are art, science and morality, which came to be differentiated as unified religion and metaphysics collapsed. Furthermore,

Since the $18^{\text {th }}$ century, the problems inherited from these older world-views could be arranged so as to fall under specific aspects of validity: truth, normative rightness, authenticity and beauty. They could then be handled as questions of knowledge, or of justice and morality, or of taste. Scientific discourse, theories of morality, jurisprudence, and the production and criticism of art could in turn be institutionalised. (Habermas 9)

The point here is that criticism and literary scholarship are part of the rise of what Habermas calls 'aesthetic-expressive rationality' and its institutionalisation. For Adorno and Horkheimer, this would have meant that literary and aesthetic pedagogy were themselves linked to the dialectics of enlightenment. Critique itself, especially as it is institutionalised in universities and academies, may be part of the machinery of reification and domination.

It may be that the "proper business of any critical theory is not to validate a pregiven political position, whether to the left or right' (Cleary 7), as Cleary says, but a critical theory also needs to have a clear sense of where it lies on the terrain of civil society, and that most of all when it wishes to make interpretative claims on the terrain of the political. Cleary is not explicit as to how he conceives of his own practice; for him to be so, he would have to elaborate the critique of the 'historical conditions of operation of the [cultural/intellectual] field itself' which he suggests is necessary for cultural change (Cleary 137). This is a task which Outrageous Fortune, in spite of its methodological self-consciousness, largely eschews, and which Irish Classics confidently bypasses. It is hard to avoid the sense that Cleary is unsure of the public to which his project of critical negation is addressed; while Kiberd, writing in a deliberately accessible register and publishing with a nonacademic house, is confident of his position in the public sphere. Contrasting Cleary and Kiberd reveals the problems of 'radical' criticism in a wider setting characterised by the capitalisation of culture, the disappearance of politics, the attenuation of the public sphere and the absence of institutionalised counter-cultural resources.
Simone Chambers, in a recent essay on the politics of Critical Theory, suggests that Adorno and Horkheimer were accused of having no politics on at least three grounds: firstly, that they adopted no open party politics; secondly, that they were chiefly concerned with the superstructural and the cultural; and lastly, and perhaps most damningly, that their pessimism itself disabled a positive politics. She defends them to the extent that she notes that they continued to theorise even in the darkest times, and that they continued to maintain that the mere cultivation of interiority is to accede to the world of commodification and domination. Chambers sees in Adorno and Horkheimer, finally, a politics of 'engaged withdrawal'; a 'Socratic enterprise of cranky admonishment and moral dressing-down' (223).

In 1927 Carl Schmitt had argued in The Concept of the Political that modern bourgeois liberal politics is based on compromise; hence, all its solutions are temporary, contingent, never decisive. Further, on this basis, equality and democracy are incompatible; the universalism of equality will always challenge the legitimacy of liberalism, which rests on discussion and shifting majorities. And further again, liberalism undermines the political, to the extent that it undermines struggle and replaces it with procedure. Thus, legitimacy and legality are in contradiction to each other.

Schmitt strangely parallels Horkheimer and Adorno in suggesting that, in modern liberal society, the political is hidden or even erased. Matching the Frankfurt analysis of the self-reification of intellect and society in the form of bureaucratic rationality, Schmitt suggests that liberalism looks for the fragmentation and de-politicisation of the full span of human activities. Adorno and Horkheimer accept these distinctions, and choose to work within them. Certainly, in Schmittian terms, Adorno and Horkheimer have renounced the political.

We find a proximate configuration of the range of possibilities in radical Irish criticism. Cleary's version of critical theory - for all its admirable and welcome iconoclasm and capacity for critical negation - does not openly advance the minimal normative project of Horkheimer and Adorno. In contrast, Kiberd's work suggests that culture and criticism help to produce the good - an apparently depoliticised universalised version of the good, though of course the depoliticising manoeuvre is itself highly political. Embedded within Kiberd's criticism there seems to be a welcoming of the 'end of history' or the 'end of ideology'; the implication is that 'normal' criticism can now resume its task, interrupted by decades of low-level war and social strife. Neither project turns back to examine the grounds of its own authority, yet one notes that Kiberd's criticism, in the Blochian act of anticipating or even announcing the end of critical 'politics', makes the more confident political move. In this alignment, we see the homology between Irish criticism and the wider socio-political system, a set of relationships which all Irish critics need to consider as they ponder their future. 


\section{Works Cited}

Anderson, Perry. A Zone of Engagement. London: Verso, 1992. Bloch, Ernst. 'Art and Utopia'. The Utopian Function of Art and Literature: Selected Essays. Trans. Jack Zipes and Frank Mecklenburg. Cambridge, Mass.: MIT P, 1988. 78-155. Chambers, Simone. 'The Politics of Critical Theory'. The Cambridge Companion to Critical Theory. Ed. Fred Rush. Cambridge: Cambridge UP, 2008. 219-47.

Cleary, Joe. Outrageous Fortune: Capital and Culture in Modern Ireland. Dublin: Field Day, 2006.

Deane, Seamus. "“Heroic Styles: The Tradition of an Idea” in Field Day Theatre Company'. Ireland's Field Day. London: Hutchinson, 1986. 43-58.

Gramsci, Antonio. Selections from the Prison Notebooks. Trans. and ed. Quentin Hoare and Geoffrey Nowell-Smith. London: Lawrence and Wishart, 1971.

Habermas, Jurgen. 'Modernity: An Incomplete Project'. Postmodern Culture. Ed. Hal Foster. London: Pluto P, 1985. 3-15. Hederman, Mark Patrick and Richard Kearney. 'Editorial 1/Endodermis'. The Crane Bag I.1 (1977): 3-5.
Hegel, G W F. Elements of the Philosophy of Right. Ed. Allen Wood. Trans. H B Nisbet. Cambridge: Cambridge UP, 1991. Howard, Dick. Defining the Political. Minneapolis: U of Minnesota P, 1989.

Kiberd, Declan. Irish Classics. London: Granta, 2000. Koselleck, Reinhart. Critique and Crisis: Enlightenment and the Pathogenesis of Modern Society. Cambridge, Mass.: MIT P, 1988.

Longley, Edna. The Living Stream: Literature and Revisionism in Ireland. Newcastle-upon-Tyne: Bloodaxe Books, 1994.

Marx, Karl. Early Writings. London: Penguin, 1975.

O'Toole, Fintan. 'The Man from God Knows Where. An Interview with Brian Friel'. In Dublin 28 Oct. 1982: 20-23.

Schiller, Friedrich. On the Aesthetic Education of Man. Ed. and trans. E M Wilkinson and L A Willoughby. Oxford: Oxford UP, 1967.

Schmitt, Carl. The Concept of the Political. Trans. George Schwab. Chicago: U of Chicago P, 1996.

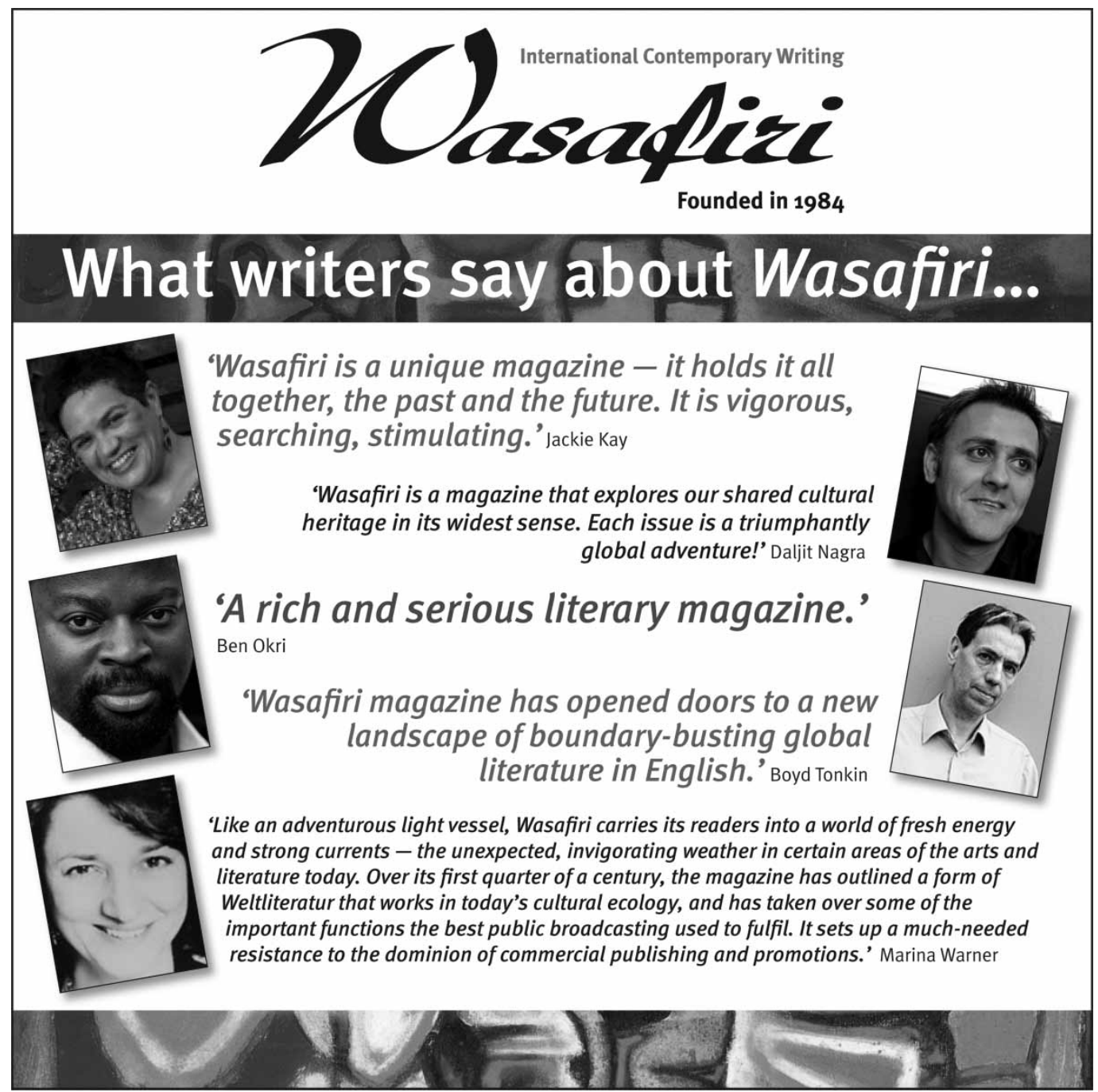

